\title{
Electric Lights and Clouds of Dust: A Reading and Translation of Nguyễn Trong Hiệp's Paris, capitale de la France / 大法國玻璃都城襍詠
}

\author{
Charles RICE-DAVIS' ${ }^{1}$, Mia NAKAYAMA² [0
}

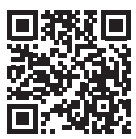

'Lecturer, Victoria University of Wellington School of Languages, Wellington, New Zealand

${ }^{2} \mathrm{PhD}$ Candidate, Ruprecht-Karls-Universität Heidelberg and Università Ca' Foscari, History Departments, Heidelberg Germany/Venice, Italy

ORCID: C.R.D. 0000-0002-9929-308X M.N. 0000-0002-5818-4303

\section{Corresponding author:} Charles RICE-DAVIS,

Victoria University of Wellington, School of Languages, Wellington, New Zealand

E-mail: charles.rice-davis@vuw.ac.nz

Submitted: 24.02 .2020

Revision Requested: 31.05.2020

Last Revision Received: 16.06.2020 Accepted: 28.08 .2020

Citation: Rice-Davis, C. \& Nakayama M. Electric lights and clouds of dust: A reading and translation of $\mathrm{Nguyễn} \mathrm{Trọng}$ Hiệp's Paris, capitale de la France / 大法國 玻璃都城襍詠. Litera, 30(2), 645-662. https://doi.org/10.26650/LITERA2020-0037

\section{ABSTRACT}

In the very large critical body on the work of Walter Benjamin, little (and only passing) attention has been devoted to the epigraph of Benjamin's 1935 exposé, "Paris, Capital of the $19^{\text {th }}$ Century," a twice-delivered working paper central to his project on the modern city. This epigraph-which also appears at the head of the English-language edition of Benjamin's collected Arcades Project which has spawned so much work in urban studies - is taken from a rare book of verse written in French and Chinese, published by the Vietnamese diplomat Nguyễn Trọng Hiệp. Paris, capitale de la France offers both historical insight and an estranged perspective to the shifting urban landscape of fin-de-siècle Paris. And also to Benjamin: what did he find pertinent about such an obscure work and why does he give it such a prominent place of its own? More broadly, Nguyễn's documentary style, both in tone and subject matter, reflects his high-level administrative background and interaction with the colonial Empire. Aesthetic observations are coupled with remarks about traffic patterns, the number of floors in residential buildings and which department stores have the most customers, as Nguyễn documents the technology, practices and "resources" of France. Finally, we offer a translation of the thirty-six poems, drawing from both French and Chinese versions of the text.

Keywords: Walter Benjamin, 19 $19^{\text {th }}$ Century Paris, Bilingual Poetry, Urbanism, Vietnamese in Paris 


\section{Introduction}

Two very small, light verses sit at the threshold to Walter Benjamin's gargantuan archival undertaking on the passages, Paris, the Nineteenth Century, the modern world. Even in its earliest integral form, his 1935 exposé, "Paris, Capital of the $19^{\text {th }}$ Century," Benjamin begins with the epigraph (Benjamin, 1999; translation ours):

The waters are blue, the plants pink, the evening's appearance is delightful. One strolls: "the great ladies walk together, followed by the lesser ladies."

[Les eaux sont bleues, les plantes roses: I'aspect du soir est charmant.

On se promène: "les grandes dames marchent ensemble, suivies de petites dames]

For a writer like Benjamin, whose sprawling practice of citation (editor Rolf Tiedmann counts 850 texts cited in the documents) may itself constitute a new form of poetics (Perloff, 2012), the prominence accorded to these verses merits a further look. Indeed, this was a less-than-obvious choice, and not only because of the verse's obscurity. The two lines are taken from a collection of thirty-six annotated poems published in Hanoi, 1897, by a retired diplomat formerly stationed in Paris, Nguyễn Trọng Hiệp (Nguyễn, 1897). ${ }^{1}$ The edition was bilingual, with parallel versions of the poems in French and Chinese (though Benjamin's citation does not mention this fact). The title of this small book, Paris, capitale de la France ${ }^{2}$, even parallels the title of the exposé, perhaps even serving as a model from which Benjamin "[transposed] place to time, thereby creating a spatio-temporal approach to culture that fixes Paris as the central locus of modernity" (Hibbitt, 2017).

The poems share features with other poetic works from which Benjamin drew inspiration, like Baudelaire, or especially Louis Aragon's Le Paysan de Paris (Paris, 2013). Namely, Nguyễn's poetic gaze meanders through Paris, reflecting on the details and development of the modern European city-technological, organizational, commercial and social—making it possible to"imagine Nguyễn Trong Hiep trailing in the clandestine

1 For further detail on the publication of the collection, and specifically the Hanoi-based Schneider publishing house, see (Pham, 2011). On his diplomatic activity in French Indochina, see (Davis, 2017).

2 The Chinese title (大法國玻璃都城襍詠), underscores the capital's use of pane architecture by referring to it as a capital of glass (玻璃都城), and not its frequent appellation as a capital of flowers (花都). 
shadows behind Baudelaire" (Lor \& Wu, 2017), with both serving as advance scouts for Benjamin's own investigations. Nguyễn, both in his diplomatic posting and his consideration of developments potentially applied to his home context (then under French colonial control), also connects himself, for a reader like Benjamin, to planners like Fourier and especially Haussmann (including Haussmann's poetry), both of whom are cited frequently throughout the passages dossiers.

In addition to its appearance-and eventual disappearance-from the top of Benjamin's project, Nguyễn's poetry offers interest in its own right. His stranger's gaze, cast upon a time and place of tremendous significance to histories of urbanisation, capitalism and Empire, has served to attract attention to his small book, especially in the years since this exceptionally rare book was digitised in 2010 by the Bibliothèque nationale de France. In light of this new interest, we have included, for the first time, a translation of all thirty-six poems as an annex to this article. Our translation from the French and Chinese informs our reading, and vice-versa. And indeed, both are informed by the text's bilingualism, which speaks to the author's own positioning in relation to his audiences and his goals, as he understood them. The instances of non-correspondence between the French and Chinese parallel versions underscore both the novelty of much of the new urban and technological developments catalogued by Nguyễn, and his careful consideration of the two respective audiences. Rather than the identical copies, the two texts form a single "diptych" (Grutman \& van Bolderen, 2014), which reveals more as a whole than each side does individually. What does this text, occupying a marginal place in Benjamin's consideration of his most consuming urban investigations, tell us about the role of the non-European subject in his project? And being led back to Nguyễn via Benjamin, how might this very different precursor make it possible to see turn-of-the-century Paris in a new light?

\section{The Stranger's Gaze}

Nguyễn's outsider's perspective and planner's gaze together serve to make Paris, Capitale de la France a well-placed parallel lens for Benjamin's project. So too does his method. Though he would have preferred to dedicate a "long poem to the illustrious capital," his time is constrained by his diplomatic work, and as such, he explains, "I gave myself the chance to reproduce, in these thirty-six quatrains, the impressions I had over the course of my strolls through Paris" (Nguyễn, 1897). Like Baudelaire and Aragon, therefore, his approach will follow the path, though not the marginal social standing, of 
the flâneur. Nguyễn's orientation and interests can best be seen in the two most remarkable, alternating currents that pervade the poems: his penchant for documenting difference and strangeness, and his analytical, technical gaze, employed in the interest of either applying or rejecting technological and ideological developments to his home country.

The Eiffel Tower description (XXIII), for example, exhibits both tendencies. Its strangeness can re-emerge for readers who know the tower well: "A great tower of iron, whose metal pieces crisscross like the threads of a spider's web / Rises in the air and gives a strange appearance." Likewise, we see the tower re-contextualised into a global, not simply European mythological language:"Even the magical genius, Zhang Guolao, didn't have in his belly a forge as adept (as that of the author of this monument)." Moreover, his pattern of directing attention to "the marvels of modern industrial capitalism" (D. L. Nguyen, 2018) extends beyond monuments and urban features into territory hardly associated with poetry. This includes, for example, the printing of paper money (XXXII):"Under the Tông and Nguyễn dynasties, bank bills were put into circulation. / But this system was not as perfect and praiseworthy as the modern system so widespread in Europe / And so profitable to commercial transaction and government finance."

An estranged perspective, such as Nguyễn's, makes it possible for readers to"revitalise our dull perceptual habits" and "learn to look at things from a distance"(Ginzburg, 1996). More broadly, this foreignising filter can be reapplied to Benjamin's "threshold," which simultaneously separates and joins $19^{\text {th }}$-century Paris and $20^{\text {th }}$-century Berlin, and indeed any modern, capitalist city. One is led to ask about Benjamin's project, "what happens to such a threshold when we see that [Nguyễn's] impressions of Paris were informed by Chinese treasures?" (Lor \& Wu, 2017). Such reframing happens in cases like the doubling of Gustave Eiffel and Zhang Guolao (張果老), a figure of the Taoist immortal pantheon. The potential for expanding this threshold is infinite: "Paris is intertwined, unquestionably, with Berlin in Benjamin's account, but also, via Nguyễn, with Hanoi (and so on, through all its various material relations with the world)" (Bartolovich, 2002).

\section{Cities Here and There, Real and Imagined}

Starting, he claims, from the very moment he descended from his coach, Nguyễn sets about documenting the city, strolling from sight to sight, advancing his understanding 
of this city through his method of "montage rather than a dominant single narrative" (Hibbitt, 2017). He begins with general remarks, about how Clovis founded the state more than a thousand years ago on very solid foundations, how the Seine flows through the centre like a silver ribbon, how many bridges there are: 24 . He's especially struck by the presence, quantity and quality of footpaths for strolling, and roads for coaches (III):

From all sides, coach traffic lifts up dust from the street in a kind of iridescent cloud

Uninterrupted processions of walkers come and go ceaselessly.

This activity heats the air, so one must need to shower or flap at their shirts to keep cool.

Fortunately, there are thousands of fountains whose spray freshens this crowded atmosphere.

He mentions coaches in seven of the thirty-six poems, noting approvingly their role in mobilising the city's population. Before turning his gaze on specific sites, he also remarks upon the sheer quantity of people, not just these "uninterrupted processions of walkers" coming and going endlessly, but also the "great crowds" of people who have to be housed, and are lodged in this strange Parisian way.

And most noteworthy of all is the mass-scale, synchronised artificial lighting, the technological innovation which makes this endless succession of human activity truly incessant (IV):

Nothing but lovely houses, and beautiful mansions, each following the next, form long chains.

At sundown the noise of coaches still creaks on.

Suddenly, one is surprised to see the stars falling from space.

For the thousands of lights lessen the effects of night's darkness.

The author's efforts to recreate the experience one has when witnessing the technologized city for the first time find a methodological echo in his practice of describing Parisian landmarks in allusion to Chinese and Vietnamese sites. He does so for example in his poems on both the Bois de Boulogne and the Bois de Vincennes. Given this cataloguing of similarity and difference, a somewhat reductive reader might cast this project as a real-life Persian Letters. Which is more or less what we get from the 
hyper-prolific novelist, journalist, and dramaturge, Jules Claretie, writing in his 28 January 1898 Vie à Paris column in Le Temps:

These are not the old, derisive exchanges sent by Usbek to Rhédi or Ibben to Usbek. These are the sincere and oddly enthusiastic impressions of a real, authentic Asian published for the purpose of showing to his compatriots the enchanted land where he was sent on his mission. And this Eden, this land of dreams and choices, is Paris (Claretie, 1899).

This may ultimately say less about Nguyễn than Claretie himself, who, quite the booster, takes it upon himself to defend Paris from its 'anglo-germaniques' critics, who have cast the city as Paris-Sodome, Paris-Vice, Paris-Cloaque (Paris-Cloaca).

What can be argued more convincingly: this short review, the only contemporary account beyond a simple title listing, is very likely how the verses made their way from Hanoi to the epigraph of Benjamin's 1935 exposé. Benjamin cites Claretie and his column, which ran from 1880-1910, repeatedly. Furthermore, Claretie's quite precious remark can also be applied more earnestly about our diplomat/ poet: "Speak to him about the underground passages which radiate in all directions below the boulevards. The sewers! He has swiftly understood their beauty" (Claretie, 1899). The qualification of "beau" and even more commonly "charmant" are applied to a wide array of urban features and infrastructure, always with an eye toward both their aesthetic traits and the practical attributes, very much in line with Benjamin's interest. The Jardin des plantes, the Bois de Boulogne, the Bon-marché, the Arc de Triomphe, the Bois de Vincennes, the Musée de Luxembourg, the Panthéon, the Musée d'Artillerie, the Opera, the Val-de-Grâce military hospital, the Grand-Hôtel des Postes et du Télégraphe, the Hôtel des Monnaies (National Mint) all get their own aesthetic description.

For all of his doubtlessly sincere and practically-minded praise of the city he documents, however, Nguyễn is also very interested in a city that does not merely exist at a given historical juncture. Often, when he does refer to particular Parisian institutions, Nguyễn does so only to then turn and place his argument into a context of utopian or universalist narratives of peace and progress. The French Sénat only succeeds because, or when, it participates in the one "true reason": something simultaneously ancient and contemporary, again something not limited to this modern and European setting (XXIV). In his explanatory note, the poet bridges the historical 
and geographical distance explicitly, writing, "The democratic spirit has long existed in China; according to the canonical book Tho-kinh, in antiquity, both government experts and subjects were asked for their opinions. This old institution is still practiced in the French parliament" (XXIVn). This historical and geographical re-centring serves to remind French-language readers that no nation has a monopoly on progress-the Qin dynasty reforms in statecraft he has in mind predate the European state by some two thousand years.

Likewise, Nguyễn's identification of positive developments in modern Paris do not simply signal innovations to be compared or applied to non-European settings. They point toward future, utopian developments that might flourish in the cities to come anywhere in the world. The edifice of a prison is evoked, for example, not to discuss its structure, but the prospect of its eventual elimination. Though "nothing has been left aside in the pursuit of justice" (XXIX), he also projects forward his hopes: "O! May we finally be led to the joyous time of the golden age, / Where the Court of justice, free of plaintiffs, would become a verdant pasture." Similarly, the fire prevention techniques necessitated by the crowded residential apparatus of the city not only signal a technical advancement which might be instituted in all cities, but the humane application of planning and technology in the interest of world peace. Inspired by Paris' fire control techniques, he writes:"If the work of Governments were all so prepared, / Peace would reign the world over" (XXII).

Finally, in addition to Nguyễn's technological curiosity, we find a parallel optimism and faith in progress in his humanistic interests. Strolling through the Musée de Luxembourg $(\mathrm{XVI})$, he remarks on the potential future growth in human understanding:

Sculptors and portraitists have the trying task of depicting men of antiquity. So it appears that skill and work might lead to this culmination of genius. If one succeeds in perfectly reproducing nonphysical things like the reflection of light,

One is able to faithfully depict the passions of the human heart.

In a similar vein, the poet expresses hope for a politics, unbounded by the "many differences between ways of governing Europe and Asia," ${ }^{3}$ but driven by the "certain

3 On his differing terminologies (references to "Asia" appear in the French but not the Chinese) here, see our note to poem XXXVI. 
immutable principals for governing a country" (XXXVI). Since the "one true reason" is ultimately "the same for all countries," such lessons could be equally directed at his French-language and Chinese-language readers.

\section{Epilogue to an Epigraph}

This matter of a potential bilingual, international readership beckons a return to the matter of Nguyễn's place in Benjamin's epigraph. In a basic way, the two lines describing ladies strolling speak to the configuration, or reconfiguration of urban space, viewed through the intersection of poetry and technology in the original locus of the modern capitalist city, Paris. They serve as an example of structured leisure taken in public along lines mobilized and guided by curated spaces, with a nod to class signalling (grand, grandes and lesser, petites). And more broadly, Nguyễn's project does indeed speak thematically to Benjamin's two massive, unfinished and overlapping targets: his work on the arcades or passages and his work on Baudelaire. The question of their inclusion at the head of the 1935 exposé is complicated by their subsequent removal from not only his 1939 exposé, but from his Arcades archive entirely, removing "one of the few non-European voices in Benjamin's work" (Bartolovich, 2002) and making it a less convincing proposition to "read the Arcades Project in its entirety from the perspective of the French colonialist enterprise" (Erber, 2019).

We have raised the possibility that Benjamin came to this obscure work through Claretie, whom he read and cited extensively. And Claretie cites the same half poem that Benjamin would later include. Two more verses follow, however:

It is a pleasure to find here the explanation of Cô-dè verses.

The passage from the book Nhae-phu is certainly very beautiful (XXV).

Nhae-phu, or Yuefu, are collected musical poems, one of the two "most conspicuous genres of the Han dynasty" (Su, 2008). Nguyễn remarks in a note to the poem that "Seeing Parisian women strolling at night, the author is reminded of the verse he had read in the Nhae-phu, and he admires that its beauty was made manifest" (XXVn). In other words, these Parisian ladies are doubles; they move simultaneously in fin-de-siècle Paris and Han dynasty China. They are quotations for Nguyễn, just as they are for Benjamin. 
This would have posed a potential difficulty for Benjamin, both textually and contextually. To the former, the two verses connect to a translation of a citation of an anthologised, unattributed musical poem Nguyễn had memorised. If, too, Benjamin had found the verses through Claretie and then gotten hold of a copy of Paris, capitale de la France, he would have found a book which is half in Chinese. How would he approach it? Claretie, for his part, refers the book as a work in Chinese with a French translation, but this is not obviously the case. Furthermore, not only would Benjamin struggle to track down an original source for the citation, but the reference to the Yuefu poem would clash with the historicity of hits project.

Ultimately, Nguyễn's documentary style parallels his unconventional (to European readers) observations as a non-western statesman. He offers heterogeneous visual information, delivered with compensatory simplicity, of living conditions in 19th-century Paris, noting practical, concrete details, as in poem V: "Six or seven-floor dwellings are linked together without discontinuity. / Even the basements are partitioned into small compartments."This acknowledgement that Paris has been constructed to correspond to human needs of space under the metropolitan culture serves to remind readers present and future, reading in Chinese or French, that infrastructure is never wholly divorced from social condition. Though his sense of history may ultimately differ from Benjamin's, his work should serve as a unique and powerful, internationally-minded literary and historical perspective. The same can be said of the very construction of Nguyễn's volume. The bilingual text may serve in its very nature as a challenge to the model of "one country, one subject," drawing attention to the "fault lines in the notion of language and person" (Hokenson and Munson, 2007). We return to the image of the ladies strolling through Paris. To one reader, they are subject to an historical upheaval they themselves don't see. To another, they reenact the verses of a centuries-old poem they could not have read. Paris may be the capital of the Nineteenth Century, but by the multiplicity of readers, passers-by, languages spoken and precedents to be cited, Paris (like any city), is never alone in space and time.

\section{A Note on Translation}

Following the indication of the author and publishers, we have treated the two languages of the text as equals, languages of acquired mastery by the highly-educated diplomat, rather than, as Claretie claimed, one as a translation of the other. Where differences in meaning exist, we have included notes, signalling the French and/or 
Chinese. In a small number of cases, we have preferred a clearer phrase from one of the languages over an ambiguous phrase in the other. For example, in Poem III, we indicate from the Chinese, "flap at their shirts to keep cool" rather than the "cooling remedies" of the French text. Finally, we have conserved Nguyễn's transliterations, noting Chinese characters and more conventional transliterations where appropriate.

\section{Appendix: Paris, the Capital of France}

I

Clovis founded a powerful State on quite solid foundations

More than a thousand years ago, in this most rich and lovely land.

Our mission arrived at the start of Spring, when this air is distinctly sweet.

From the moment I left my coach, I gave myself the task of singing this great capital's praises.

II

Palaces and magnificent halls ${ }^{4}$ spread their superb roofs against the azure sky.

Like a silver ribbon, a river of gleaming water flows through the city.

There are delightful paths which strike visitors in bursts of manly energy.

Each night, thousands of lights shine across the twenty-four bridges.

III

From all sides, coach traffic lifts up red dust from the street in a kind of iridescent cloud ${ }^{5}$ Uninterrupted processions of walkers come and go ceaselessly.

This activity heats the air, so one must need to shower or flap at their shirts to keep cool. ${ }^{6}$

Fortunately, there are thousands of fountains whose spray freshens this crowded atmosphere.

IV

Nothing but lovely houses, and beautiful mansions ${ }^{7}$, each following the next, form long chains.

4 城關(Cheng-Guan): Castles with gates, a governing symbol of the regions; hôtels.

5 地紅(Dihong); the ground turns red

6 In the French, remèdes réfrigérants.

7 Hôtels, 閣 $(\mathrm{Ge})$ / 樓 ( $\mathrm{LOU}$ ): These architectural terms indicate the buildings in questions are more likely to function as residential properties instead of governing symbols. 
At sundown the noise of coaches still creaks on.

Suddenly, one is surprised to see the stars falling from space,

For the thousands of lights lessen the effects of night's darkness. ${ }^{8}$

$\mathrm{V}$

Six or seven-floor dwellings are linked together without discontinuity.

Even the basements are partitioned into small compartments.

This is to house the inhabitants who have thronged the city in great crowds

And to hold the vast quantities of wealth produced by industry and commerce.

$\mathrm{VI}$

All things rare and beautiful from the plant and animal kingdoms have been gathered here.

All are arranged to please everyone, in heated galleries or cooled greenhouses.

Here, one sees the thirty-six enchanted and immortal gardens,

Without ever seeing autumn or the falling of leaves.

VII

Coming from India to Europe, the climate is quite different.

One sees nothing but strange ${ }^{9}$ flowers and new plants.

One is surprised to find, in this country of glacial winds and frigid cold,

Our "wise bamboo" standing tall and green.

VIII (Bois de Bologne)

To the west of the city, there is a delightful forest

Of pleasant hills and verdant trees,

Of little lakes, and in the distance, two race tracks

One can imagine the Truong-duong ${ }^{10}$ contest taking place here. ${ }^{11}$

\section{Bon-marché}

An immense house open on all sides ${ }^{12}$

8 不夜天(Bu ye tian): The day will turn into night.

9 Strange (奇 qi) flowers and unique (異 yi) plants.

10 長楊(Chang-Yang), a royal hunting ground/Palace during the Han Dynasty.

11 Author's note: Truong-duong, the name of the hunting palace built by the emperor Tanh-dê, 32-6 BC, during the Han dynasty.

12 In Chinese, "the house sits West and faces East." 
An echoing of the murmur of the tides of buyers and thousands of objects for sale, and whose incomparable splendour deceives the eyes.

It looks like the "City on the Sea" transplanted to the middle of the Capital. ${ }^{13}$

\section{X (Statues on the streets)}

Illustrious men from all ages, whose memories have already been preserved in history Still stand upright against the sky in beautiful majesty.

$\mathrm{Xi}$-di is certainly worthy of a statue cast in cold,

So that, a thousand years from now, on might contemplate him and preserve his memory.

XI

A brilliant colossus sought to cross the world with his millions of men.

His arms caused the entire earth to tremble

Facing the superb Arc de Triomphe and the sculptures, which admirably show military scenes,

One witnesses the battles of this glorious age.

XII (Palais-Royal)

A magnificent and spacious palace built of lovely hewn stones.

It is the august former residence of kings, I am told.

It now shelters thousands of individuals.

Gazing upon it, one understands the resources and grandeur of this the country that built it.

\section{XIII (Jardin des Plantes)}

$A$ vast garden includes buildings facing in every direction.

It contains rare animals and rare birds from distant lands.

On the upper floors of the Museum, there are skeletons of all species, most of them very strange;

In seeing them, one feels a sensation of horror, one's hair stands on end.

13 Author's note: According to the Chinese legend, when the images of colours form on the surface of the sea, it is said that it is immortals who have assembled for their market, so it is called Haî-thî or Market of the sea. The author compares this shop to the market of the immortals 


\section{XIV}

Dense leaves of a thousand interlaced branches cast delightful shadows.

Slender grass, as soft as a rug, circles fountains of clear water.

Each day, an unending number of strollers come;

And when the sun casts down its slanting rays, or a light breeze blows, the coachmen hold their whips still.

\section{$\mathrm{XV}$ (Bois de Vincennes)}

An arrow's flight away, on the East side of the city, there is a wood like a forest.

Scattered with charming creeks, blooming flowerbeds and shaded paths,

In the middle of a bustling, prosperous capital,

where the eyes have their fill of the spectacle of dusty coaches,

One is surprised to be suddenly transported,

like in a beautiful dream, onto Mount La-phu' ${ }^{14}$, or Chinese Olympus.

\section{XVI (Musée de Luxembourg)}

Sculptors and portraitists have the trying task of depicting men of antiquity.

So it appears that skill and work might lead to this culmination of genius.

If one succeeds in perfectly reproducing nonphysical things like the reflection of light, One is able to faithfully depict the passions of the human heart.

\section{XVII (Panthéon)}

On the pediment of the doorway, these words are written:

To Illustrusious men, the Fatherland is grateful.

This monument is vast, tall and imposing.

Inside, there are murals and statues depicting the great men of the past.

I regret that my translation of French History is not sufficiently fluent to understand all the scenes shown.

XVIII

The city is crisscrossed in all direction $\mathrm{s}^{15}$ by many streets.

There are also underground passages spanning out in all directions. ${ }^{16}$

14 Author's note: The enchanted mountains, sojourn of the Buddhas, 羅浮.

15 The Chinese describes as follows the directions (八方; ba fang): Eight directions: East, West, North, South. Northeast, Northwest, Southeast, Southwest.

16 Here, 四通 (si tong) : four directions: East, West, North ,South 
One goes through the sewers in coaches so muffled that noise sounds distant.

One is surprised to find the shining pearls of Giao-cung. ${ }^{17}$

XIX (Musée de l'Artillerie)

In this vast monument, arms are sorted, with orders,

Perfected daily by the progress of advancing studies.

Many are so old and so strange

That it is difficult to find names for them.

\section{XX (The Opera)}

On the grand boulevard, a magnificent theatre rises up.

Inside, the gilding and paint glimmer in a lively sheen beneath the thousands of lights.

One hears artists sing very well, and sees, above all, such pretty dancers,

Like fairies enacting Nghè-thuong ${ }^{18}$ in the Palace of Quan-han.

\section{XXI (Val-de-Grâce)}

France, renowned outside its border as a military power,

takes great care for the maintenance of its troops.

III soldiers are treated with concern, and its medical science is most perfected.

How might this invaluable science be applied to the suffering of nations?

By silencing calls for war in the four corners of the world.

\section{XXII}

Houses pressed up against each other bring risk of fire.

There are waterspouts ${ }^{19}$ (which seem to send whirlpools into the air).

If all Governments were all so prepared in their work,

Peace would reign the world over.

\section{XXIII (Eiffel Tower)}

A great tower of iron, whose metal pieces crisscross like the threads of a spider's web Rises in the air and projects a strange appearance.

Even the magical genius, Truong-qua ${ }^{20}$, didn't have in his belly a forge as adept As that of the author of this monument.

17 Author's note: Giao-cung, a mythical underwater palace.

18 A musical piece.

19 水龍 (Shui-Long), water dragons

20 張果老(Zhang Guo-Lao) 


\section{XXIV (The Senate and Chambre de Députés)}

True reason is at all times most impartial.

One must "ask the opinions of one's advisors as well as one's subjects."21

Today, in this vast palace where the affairs of State are honed

I was convinced I was seeing this ancient institution still working

but with new and grandiose progress.

\section{XXV}

The waters are blue, the plants pink, the evening's appearance is delightful.

One strolls: "the great ladies walk together, followed by the lesser ladies."22

It is a pleasure to find here the explanation of Cô-dè ê $^{23}$ verses.

The passage from the book Nhae-phu ${ }^{24}$ is certainly very beautiful. ${ }^{25}$

\section{XXVI (Le Grand-Hôtel de Postes et du Télégraphe)}

Electricity is widely studied and used in many industries:

Like telegraphy, it scales mountains and crosses seas in the blink of an eye.

It is an inscrutable secret to the layman's world, few people know it,

Like "don sa" ${ }^{26}$ (the genie's drug of immortality), whose preparation required the ten times the heat of fire.

\section{XXVII (Faculté des sciences)}

France has a particular way of dealing with education.

For more than three centuries, this attention has only increased.

Among the sciences, chemistry is the most advanced,

Since it makes it possible to examine the combination of all bodies, even those smaller than a strand of thread or of hair.

21 Author's note: The democratic spirit has long existed in China; according to the canonical book Tho-kinh, in antiquity, both government experts and subjects were asked for their opinions. This old institution is still practiced in the French parliament.

22 The Chinese text here, like the French, uses neutral terms which may suggest class standing, but not explicityly so.

23 古題 (Gu ti)

24 樂府 (Yuefu)

25 Author's note: Nhae-phu is a book of Chinese poetry and songs, a sort of poetic anthology. In this book one finds the phrase quoted above. Seeing Parisian women strolling at night, the author is reminded of the verse he had read in the Nhae-phu, and he admires that its beauty was made manifest.

Cinnabar 


\section{XXVIII (Circus)}

In the mountains, when the tiger howls, trees shake, and leaves fall as in autumn. And when the lion roars, the other animals tremble in fear.

Who could believe that innocence could growl back at a ferocious creature, And a young girl could tame these wild beasts.

\section{XXIX (Prison)}

To the west of the city, there is a prison like the star Châp-phap in the sky ${ }^{27}$ Nothing has been left aside in the pursuit of justice.

O! May we finally be led to the joyous time of the golden age, Where the Court of justice, free of plaintiffs, would become a verdant pasture.

\section{XXX (L'Hôtel des Monnaies)}

The machines for striking coins work with the speed of wind. When they operate, one imagines the tale of gold coins raining from the sky. A beautiful collection of coins from all eras has been assembled;

Some, rusted and blemished, are hundreds of years old.

\section{$\mathrm{XXXI}$ (Bois de Boulogne)}

To the west of the city, there is a vast race course, the grandstands are splendid.

The paths surrounding the race tracks are wide; many coaches travel on them.

The competing horses are magnificent animals

Which run with the speed of wind and lightning.

\section{XXXII (The Bank of France)}

Under the Tông and Nguyen dynasties, bank bills were put into circulation.

But this system was not as perfect and praiseworthy as the modern system so widespread in Europe

And so profitable to commercial transaction and government finance.

\section{XXXIIII28}

Coming to Spring equinox, the days grow long.

At three in the morning, the sunrise starts to light the windows' glass.

27 Author's note: The star of justice in Chinese mythology, shining at the centre, so as to monitor the other constellations of the firmament.

28 The Chinese text indicates this is a hotel, 賓館 (Bin-guan). 
Free, on this morning, with no official business, I add another pinch of incense to the burner.

\section{XXXIV (Observatory)}

The chapter Thuan-dien, of the Tho-king, mentions a device made of pearls and a tube

of precious stones invented by the ancients to observe the movement of the sun. In the Minh era, European astronomy was introduced in China.

The Paris Observatory holds astronomical instruments of marvellous quality. And yet, the calculation of two calendars, Gregorian and Chinese, is made according to the rotation of the stars around the sky.

\section{XXXV (City of Le Creusot)}

In the very place where coal is extracted, there is a metallurgical factory.

Thousands of labourers work there actively.

The founder of this factory has made quite a fortune, thanks to the immense quantity of work, in mind and heart.

No character from any of the books I've read equals this industrialist.

\section{XXXVI}

There have always been certain immutable principals for governing ${ }^{29}$ a country.

Reading history, one finds many differences between ways of governing Europe and Asia. ${ }^{30}$

Nevertheless, one true path of reason exists in the world:

Reason is the same for all countries.

Évaluation : Évaluation anonyme par des pairs extérieurs.

Conflit d'intérêts : Les auteurs n'ont aucun conflit d'intérêts à déclarer.

Subvention : Les auteurs n'ont reçu aucun soutien financier pour ce travail.

Peer-review: Externally peer-reviewed.

Conflict of Interest: The authors have no conflict of interest to declare.

Grant Support: The authors declared that this study has received no financial support.

29 In the Chinese text, Nguyen uses the term 立國, which could mean 'establishing or founding,' whereas the French suggests merely 'governing.' He uses the closer term, 治國 in his notes on this poem.

30 While the French specifies Europe and Asia, the Chinese notes only a variety of styles of governing informed by history. 


\section{References}

Bartolovich, C. (2002). Figuring the (In)visible in an imperial weltstadt: The case of Benjamin's Moor. Cultural Critique, 52, 167-208.

Benjamin, W. (1999). Paris, the Capital of the Nineteenth Century (Exposé of 1935). In R. Tiedmann (Ed.), \& H. Eiland \& K. McLaughlin (Trans.), The Arcades Project (pp. 3-13). Harvard University Press.

Claretie, J. (1899). La vie à Paris: 1880-1910 (Vol. 1898). Bibliothèque Charpentier.

Davis, B. C. (2017). Imperial Bandits: Outlaws and Rebels in the China-Vietnam Borderlands. University of Washington Press.

Erber, P. (2019). The politics of strolling. Latin American Perspectives, 46 (4), 37-52.

Ginzburg, C. (1996). Making things strange: The prehistory of a literary device. Representations, 56, 8-28.

Grutman, R. \& van Bolderen, T. Self translation. In S. Bermann and C. Porter (Eds.), A Companion to Translation Studies. John Wiley \& Sons. https://doi.org/10.1002/9781118613504.ch24

Hibbitt, R. (2017). Introduction: Other capitals of the nineteenth century. In R. Hibbitt (Ed.), Other Capitals of the Nineteenth Century: An Alternative Mapping of Literary and Cultural Space (1-30). Palgrave Macmillan US. https://doi.org/10.1057/978-1-137-57085-7_1

Hokenson, J. W. \& Munson, M. (2007). History and theory of literary self-translation. St. Jerome Publishing.

Lor, P., \& Wu, F. (2017, September 1). Sisyphus' music box: A dialogue on race and interruption. C Magazine Issue 135, NP. https://cmagazine.com/issues/135/sisyphus-music-box-a-dialogue-on-race-and-interruption

Nguyen, D. L. (2018). Tourism and the irony of colonial underdevelopment in Nhất Linh's "Going to the West." Studies in Travel Writing, 22(4), 371-388. https://doi.org/10.1080/13645145.2019.1621037

Nguyễn, Trong-Hiệp. (1897). Paris, capitale de la France: Recueil de vers / composés par Nguyễn-Trong-Hiệp, dit Kimgiang. Imprimerie de F. H. Schneider. https://gallica.bnf.fr/ark:/12148/bpt6k58158290

Paris, V. (2013). Uncreative Influence: Louis Aragon's Paysan de Paris and Walter Benjamin's Passagen-Werk. Journal of Modern Literature, 37(1), 21-39. https://doi.org/10.2979/jmodelite.37.1.21

Perloff, M. (2012). Unoriginal Genius: Poetry by Other Means in the New Century. University of Chicago Press.

Pham, V. Q. (2011). Trajectoires éditoriales de la littérature francophone vietnamienne. Alternative Francophone, 1(4), 1-14. https://doi.org/10.29173/af11244

Su, J.-L. (2008). Shi Poetry: Music Bureau Poems (Yuefu). In Z. Cai (Ed.), How to Read Chinese Poetry: A Guided Anthology (pp. 84-102). Columbia University Press. 